Reckoning With the Imagination 



\title{
Reckoning With THE IMAGINATION
}

\author{
Wittgenstein and the Aesthetics \\ of Literary Experience
}

Charles Altieri

Cornell University Press ItHaCA AND LoNdon 
Copyright (๑) 2015 by Cornell University

All rights reserved. Except for brief quotations in a review, this book, or parts thereof, must not be reproduced in any form without permission in writing from the publisher. For information, address Cornell University Press, Sage House, 512 East State Street, Ithaca, New York 14850.

First published 2015 by Cornell University Press

First printing, Cornell Paperbacks, 2015

Printed in the United States of America

Library of Congress Cataloging-in-Publication Data

Altieri, Charles, 1942- author.

Reckoning with the imagination : Wittgenstein and the aesthetics of literary experience / Charles Altieri.

pages $\mathrm{cm}$

Includes bibliographical references and index.

ISBN 978-0-8014-5374-8 (cloth : alk. paper)

ISBN 978-0-8014-5670-1 (pbk. : alk. paper)

1. Wittgenstein, Ludwig 1889-1951-Aesthetics. 2. Criticism.

3. Literature-History and criticism-Theory, etc. I. Title.

B3376.W564A695 2015

$111 \cdot .85-\mathrm{dc} 23$

2014035620

Cornell University Press strives to use environmentally responsible suppliers and materials to the fullest extent possible in the publishing of its books. Such materials include vegetable-based, low-VOC inks and acid-free papers that are recycled, totally chlorine-free, or partly composed of nonwood fibers. For further information, visit our website at www.cornellpress.cornell.edu.

$\begin{array}{lllllllllll}\text { Cloth printing } & 10 & 9 & 8 & 7 & 6 & 5 & 4 & 3 & 2 & 1 \\ \text { Paperback printing } & 10 & 9 & 8 & 7 & 6 & 5 & 4 & 3 & 2 & 1\end{array}$

Cover image: Pablo Picasso, Woman Reading, 1920. @ 2015 Estate of Pablo Picasso / Artists Rights Society (ARS), New York. 